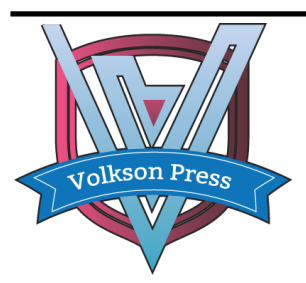

Contents List available at VOLKSON PRESS

Education, Culture and Social Development (ECSD)

DOI : http://doi.org/10.26480/icecsd.01.2018.86.89

Journal Homepage: : https://topicsonsocialdevelop.com/

\title{
RESEARCH AND PRACTICE OF CONSTRUCTING MULTI-DIMENSIONAL CURRICULUM SYSTEM OF COLLEGE ENGLISH IN LOCAL SCIENCE AND TECHNOLOGY UNIVERSITIES
}

\author{
CHEN Xiangliu, ZENG Xiangning \\ College of Foreign Studies, Guilin University of Technology Jiangan Road 12\#, Guilin, P.R. China. \\ Corresponding Author Email: ChenXiangliu@glut.edu.cn
}

This is an open access article distributed under the Creative Commons Attribution License, which permits unrestricted use, distribution, and reproduction in any medium, provided the original work is properly cited

\section{ARTICLE DETAILS}

\section{Article History:}

Received 12 November 2017 Accepted 12 December 2017 Available online 1 January 2018

\section{ABSTRACT}

Based on the three projects of "research and practice of second classroom teaching design of College English in mobile environment", "research on the setting of College English elective courses under multi-intelligence system theory" and "research and practice of 'hybrid' teaching mode of College English in Guangxi engineering colleges", this subject aims to carry out research and practice of college English curriculum system, including optimization of curriculum, improvement in teaching mode, perfection of assessment methods, construction of teaching staff. The original singleplane college English curriculum is reformed to be multi-dimensional curriculum system. More than 10 English expansion courses are provided in the whole school. The nature of the course is changed from compulsory to elective. The grade evaluation is done from usual performance, final exams and oral exams. A broad platform is provided for students to learn English, and a three-dimensional network is built to improve students' ability to use English comprehensively. Meanwhile, we have obtained some high-quality theoretical and practical research results. More than 30 educational teaching articles are published on domestic and overseas academic journals, 3 teaching materials are published. Also, outstanding results are achieved in teaching competitions at all levels, creating important influence both at home and abroad, and playing a demonstration and leading role.

\section{KEYWORDS}

Curriculum system, mobile environment, multi-intelligence, three-dimensional.

\section{THEORETICAL BASIS AND RESEARCH SIGNIFICANCE OF THE RESULTS}

\subsection{Theoretical basis of the results}

Since its implementation in 2003, the college English teaching reform has made a positive contribution in leading and promoting the reform of higher education in China and improving the overall quality of personnel training [1]. It is of strategic importance. The Office of the Ministry of Education pointed out in document No. 4 in 2006 that college English teaching reform is an important part of "Teaching Reform and Teaching Quality Project in Colleges and Universities" of the Ministry of Education. "Several Opinions of the Ministry of Education on Further Deepening Undergraduate Teaching Reform and Improving Teaching Quality in an All-Round Way" put forward the requirement of "further promotion and implementation of college English teaching reform" and pointed out that it is necessary to "effectively promote college students' comprehensive English application ability."

In today's world, economic globalization and technological progress have closely linked people from different countries and regions. As the most widely used language in the world at present, English is an important tool for international connection and technological and cultural exchanges. The state attaches great importance to the development of Guangxi's coastal areas and clearly defines Beibu Gulf Economic Zone as a key area for the western development and ASEAN cooperation. Therefore, college English teaching in Guangxi is the top priority of education reform.

College English teaching should be adapted to the requirements of times for diversification and individualization of higher education. For universities of different types and different school-running orientations, college English teaching requirements, teaching methods and teaching contents should reflect personality, localization and diversification characteristics [2]. For science and engineering college students, English has dual attributes: not only as carrier of humane knowledge, but also as tool for obtaining scientific and technological information. Through the analysis of the current situation of students' English application ability of Guilin University of Technology, this project carries out College English curriculum reform in the university; provides practical and effective theoretical and practical basis for further promoting college English teaching reform in Guangxi higher education and enhancing college students' English application ability; and constructs an English teaching system in line with Guangxi college students' characteristics that shows features of national colleges.

\subsection{Research significance of the results}

Foreign language education in universities is an important part of higher education in our country. It is of great significance for promoting the coordinated development of college students' knowledge, abilities and overall quality. As the most important content of university foreign language education, college English is a compulsory basic public course for most non-English majors in undergraduate education and plays an irreplaceable role in personnel training. "National Medium and Long-Term Education Reform and Development Planning Outline (2010-2020)" pointed out: "Improving quality is the core task of higher education development." Improving teaching quality of higher education requires that we provide quality foreign language education for college students. College English teaching, on the one hand, should meet the needs of national strategy, serves the country's reform and opening up as well as its economy and society [3]. On the other hand, it should meet students' needs for professional study, international exchange, further study and employment. 
Guangxi colleges and universities are actively carrying out college English teaching reform with students' English application ability as the teaching objective and have achieved remarkable results. There is no discussion of "dumb" English, "deaf" English in the society, English learning environment is greatly improved, and both students' abilities to hear and say are improved. However, while focusing on the development of students' common language ability, universities should further enhance students' academic English or professional English communication skills and intercultural communicative competence so that students can communicate effectively in English in different fields or contexts such as daily life, professional study and profession. College English teaching should be adapted to the requirements of the times for diversification and individualization of higher education [4]. For universities of different types and different school-running orientations, college English teaching requirements, teaching methods and teaching contents should reflect personality, localization and diversification characteristics. For science and engineering college students, English has dual attributes: not only as carrier of humane knowledge, but also as tool for obtaining scientific and technological information. Through the analysis of the current situation of students' English application ability of Guilin University of Technology, this project carries out College English curriculum reform in the university; provides practical and effective theoretical and practical basis for further promoting college English teaching reform in Guangxi higher education and enhancing college students' English application ability; and constructs an English teaching system in line with Guangxi college students' characteristics that shows features of national colleges.

\section{THE MAIN CONTENTS OF THE RESULTS}

\section{$2.1 \quad$ The basic idea}

The basic idea of the research results is shown in Figure 1:

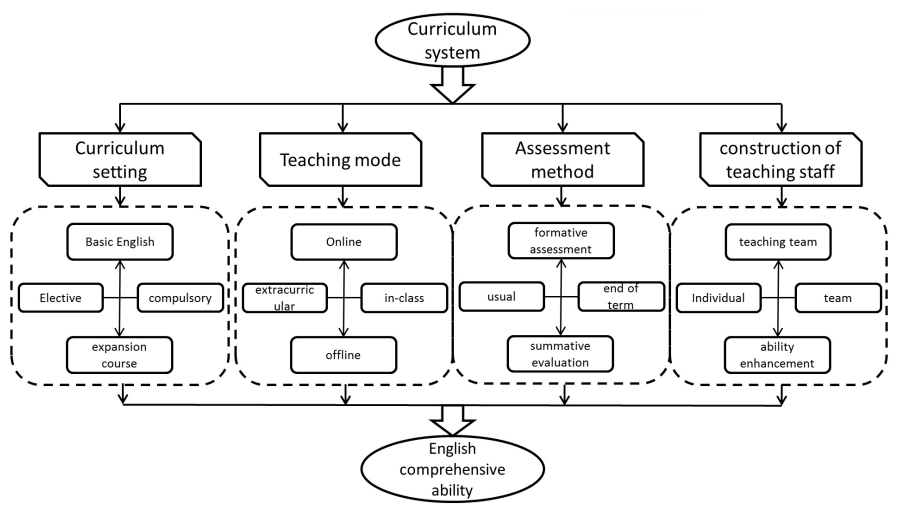

Figure 1: Research ideas

\subsection{The main teaching problems to be solved}

As the most important basic course, college English shows the following main problems before the reform: single curriculum setting, repetition of teaching contents, unclear teaching goal, dull teaching mode, lack of supervision over students' learning process and lack of scientific detection of learning effectiveness, failure to combine teachers' teaching and research, which is unfavorable to teachers' professional development [5].

This project aims to establish a multi-dimensional curriculum system and build a comprehensive learning platform for students via optimizing curriculum setting, improving teaching mode, perfecting assessment methods, building teaching staff so that comprehensive English application ability can be improved.

\subsubsection{Single curriculum setting.}

In the original college English, there is only one course, students learn common basic English for four semesters. After the reform, college English courses are set as: basic English + English expansion course. The nature of the original course is compulsory but is changed to compulsory + elective after the reform. Students can choose their favorite English courses, which both enhances students' learning interest and enthusiasm, but also achieves curriculum diversification.

\subsubsection{Traditional teaching mode.}

The traditional teaching activities only take place in the classroom. The teaching mode mainly consists of teacher classroom teaching and students' completion of homework. After the reform, classroom and computer-based teaching mode is established, classroom teaching and self-study are combined. Relying on the construction of online courses, hybrid teaching mode based on classrooms and on-line online classes such as flip classroom is implemented. Students' learning combines in-class, extracurricular, online and offline forms, English learning WeChat official account is set up to achieve three-dimensional teaching.

\subsubsection{Course evaluation method}

Course evaluation method is not scientific enough, and the evaluation is not comprehensive enough. The original examination mode takes the main form of final examination, which fails to pay full attention to students' learning process, exclude language test features, and takes an examination as the main evaluation criteria. The evaluation of students' learning is not scientific enough. In the reform, students' learning is evaluated in stages, formative assessment and final assessment are organically combined, oral examination is added to achieve diversification in assessment main body and content, assessment methods and means.

\subsubsection{Lack of teaching and research team and teacher career planning.}

Teacher's team is built from two levels, namely teacher's team level and individual level. The teaching and research team is established. For teaching content, led by teachers of higher vocational title, special teaching and research team is established for listening, vocabulary, writing, translation to combine teaching and research and enhance teachers' teaching and research capabilities. Teacher career planning is formulated, and importance is attached to teacher career planning, so that each teacher has his own direction of scientific research and development.

\subsection{Methods to solve teaching problems}

\subsubsection{Diversified curriculum settings}

In order to improve students' listening and speaking abilities, the courses offered include advanced oral English, audio-visual English and English speech. Courses to improve students' reading ability include selected readings of English newspaper and magazine. Courses to enhance students' understanding of western culture include American culture, English culture, movie appreciation, cross-cultural communication. Courses to enhance students' academic ability include translation of scientific English, English practical writing. The setting of these courses plays an important role in improving students' overall humanistic accomplishment. It enables students to broaden their horizons and enrich their life experiences through English courses, forming cross-cultural awareness, enhancing spirit of patriotism, developing innovative abilities, forming a good character and correct life concept and values.

\subsection{2 "Hybrid" teaching mode}

Advantages of traditional classroom teaching are fully displayed, traditional classroom teaching and network technology are effectively combined, and independent learning and cooperative learning are combined. "Hybrid" college English teaching mode is established in universities of science and engineering to promote college English teaching.

\subsubsection{Multi-dimensional assessment methods}

Assessment of student achievement consists of usual grades plus final grades, that is, formative assessment and summative assessment are organically combined. The usual grades cover attendance, classroom performance, homework, quizzes, teamwork, online course interaction, online computer-based test, while final grade covers oral and written exams. 


\subsubsection{Construction of teaching staff}

Teachers' team is built through the construction of curriculum system, teachers' adaptability is enhanced through curriculum construction, teachers' research ability is improved through teaching reform, and structure of teaching staff is optimized through implementation of education promotion programs.

\subsubsection{Strengthening of textbook construction}

The published textbooks include "CET-4 Vocabulary Illustration and Discrimination", "New Style English Fast Reading", "College English Reading Course" and "21st Century College English", and 2 teaching materials are in compilation: "English Newspaper Reading, British and American Culture Tutorial", "Practical English Knowledge Concise Manual for Non-English Major Undergraduates in Universities of Science and Engineering."

\subsubsection{Colorful second classroom}

The first classroom teaching and second classroom activities are organically combined to jointly promote students' English learning.

Second classroom communication QQ group is established for college English. Second classroom English website is constructed and teachers and students have feedback and exchange on website construction, use and other issues in the QQ group, which expands teachers and students' extra-curricular exchanges and guidance. Construction of network courses is strengthened, and school-level network courses have been constructed for "college English", "British and American culture", "English writing". English learning public account is set up to regularly release English learning contents. After the reform, diversified curriculum setting is shown in Table 1:

Table 1: Elective Course Setting

\begin{tabular}{|c|c|c|}
\hline $\begin{array}{l}\text { modules to enhance Eng } \\
\text { application ability }\end{array}$ & comprehensive & Elective course name \\
\hline \multirow{7}{*}{ Basic English skills } & Listening & English listening \\
\hline & \multirow{2}{*}{ speaking } & intermediate oral English \\
\hline & & Advanced oral English \\
\hline & reading & selected readings of English newspaper and magazine \\
\hline & writing & English practical writing \\
\hline & \multirow[b]{2}{*}{ translation } & Scientific English translation \\
\hline & & English grammar \\
\hline \multirow{4}{*}{\multicolumn{2}{|c|}{ Language Communicative Ability }} & Intermediate Audio-visual English \\
\hline & & Advanced audio-visual English \\
\hline & & Intercultural Communication \\
\hline & & English speech and debate \\
\hline \multirow{5}{*}{\multicolumn{2}{|c|}{ Western culture }} & American culture \\
\hline & & British Culture \\
\hline & & Appreciation of English movies \\
\hline & & Introduction to European culture \\
\hline & & $\begin{array}{l}\text { selected readings of famous European and American } \\
\text { literary works }\end{array}$ \\
\hline
\end{tabular}

After the reform, the three-dimensional teaching mode is shown Figure 2:

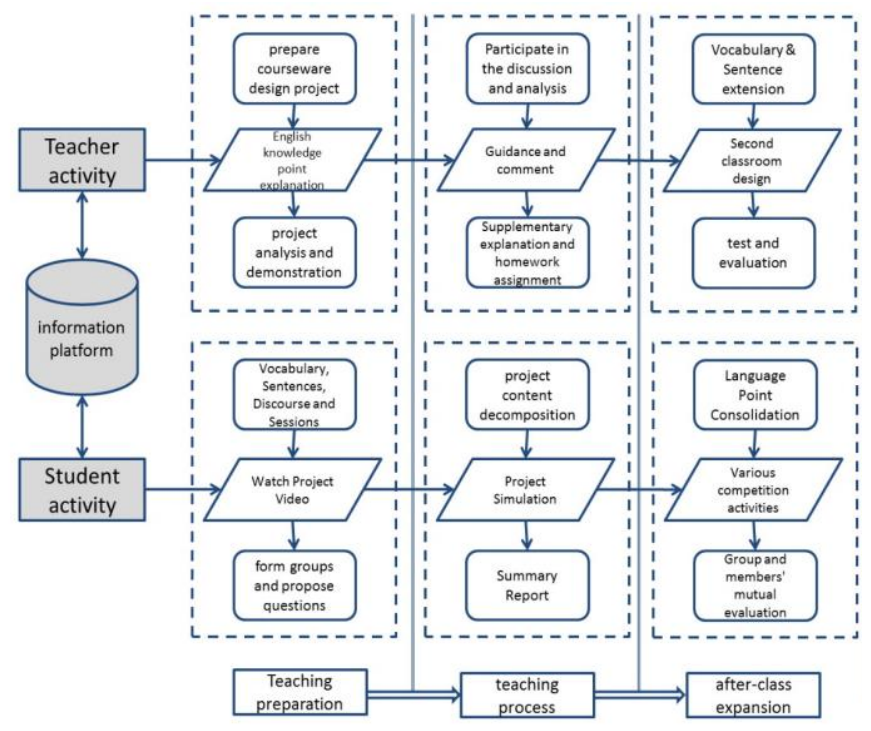

Figure 2: Three-dimensional "hybrid" teaching mode

\section{INNOVATION POINTS}

\subsection{Diversification}

The course content is diversified, including common basic English and English expansion courses, such as British culture, American culture, spoken language, speech, film and television appreciation, intercultural communication, scientific English translation, practical writing and so on.

\subsection{Three-dimensional}

dynamic and open curriculum system. College English courses consist of compulsory, restricted electives and optional electives. After completing basic English courses, students can choose 2 English expansion courses according to their own needs, which is conducive to students' individualized learning and academic planning and can meet their different professional and personal development needs.

\subsection{Innovations in teaching mode}

By utilizing network environment and personal mobile terminal devices, a mobile learning community is built for college English second classroom to form effective interaction with the first classroom, so that students experience authentic, mobile and autonomous English practice environment. 


\subsection{Innovations in assessment methods}

Students' entire learning process (usual performance, examinations, classroom and after classes) is observed, recorded, reflected and adjusted. Comprehensive evaluation is made by establishing student files, teacher observations, students' self-assessment and peer reviews to greatly stimulate students' English learning enthusiasm. The new assessment method organically combines summative tests of learning outcomes with formative test that promotes student learning.

\section{PROMOTION AND APPLICATION EFFECTS OF THE RESULT}

\subsection{Application}

This project has been implemented since 2010, and our 2010 to 2015 grade students are beneficiaries of this project. After learning basic English, students can choose two English expansion courses according to their own needs to improve their English application ability. Students' learning styles are diversified [6]. They can read books in the classrooms and libraries by traditional methods or conduct online and offline learning using computer network. Also, they can have mobile learning via mobile phone clients, truly learning English anytime and anywhere. The assessment combining formative test and summative test can evaluate student's learning effect more scientifically and effectively.

\subsection{Application effect}

English expansion curriculum effectively enriches students' knowledge of Chinese and foreign cultures, so that they understand the cultural differences between China and foreign countries, improve intercultural communication skills. Students made outstanding achievements in competitions such as "National College Students English Contest", "English Speech Contest", "Guangxi Translation and Writing Contest" and "Guangxi College Students English Drama Competition." The awards rank the top position among Guangxi colleges and universities. At the same time, teachers have continuously improved their teaching level, wining good results in competitions such as "National Young Teachers' Teaching Competition", "National Microcosm Competition", "National Multimedia Courseware Contest", "Guangxi Education \& Teaching Application Contest" and "Guangxi Young Teachers' Lecturing Contest". Teachers' research capabilities have been improved, with 30 teaching and educational reform papers, 3 textbooks published and 2 textbooks in compilation.

\subsection{Extra-school promotion}

Guilin University of Electronic Technology, Guilin Medical University, Guangxi Arts University, Guangdong University of Petrochemical Technology, Beijing University of Chemical Technology and other universities inside and outside the region have visited our school to communicate on College English teaching reform and curriculum construction. In particular, they would like to know curriculum setting and expansion curse contents. Also, Guangxi College English Teaching Steering Committee came to our school and gave high evaluation of out college English teaching.

The college English second classroom website is located on our campus network and can be accessed directly from the Internet (http:// djzhx.glut.edu.cn/english/index.asp). The schools that have used the website so far include: Guangxi Normal University, University of Electronic Science and Technology of China, Guangxi Medical University and so on.

\section{ACKNOWLEDGMENTS}

This paper represents stage results of 2016 Guangxi undergraduate teaching reform project in higher education: "research and practice of Guangxi colleges and universities to enhance students' English application ability" (2016JGA209).

\section{REFERENCES}

[1] Brown, J.D. 1995. The Elements of Language Curriculum: A Systematic Approach to Program Development [M]. Boston, MA: Heinle \& Heinle.

[2] Dudley-Evans, T., St John, M.J. 1998. Developments in English for Specific Purposes: A Multi-Disciplinary Approach [M]. Cambridge: Cambridge University Press.

[3] Yalden, J. 2000. Principles of Course Design for Language Teaching [M]. Beijing: Foreign Language Teaching and Research Press.

[4] Fu, Y. 2017. A Study of the Ecological System of College English Curriculum in Local Colleges and Universities [J]. Journal of Chendu Normal University, (12).

[5] Zheng, D.H. 2016. Constructing Multicurricular System of College English Based on Needs analysis [J]. Foreign Language World, (6).

Zou, X.Y., Chen, J.L. 2016. Research on Constructing Ecological Curriculum Group of College English Based on Two Demands [J]. Foreign Language Education, (5).

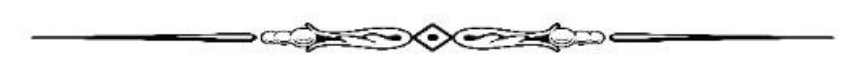

